\title{
Erratum to: Collaborative Business Ecosystems and Virtual Enterprises
}

\author{
Luis M. Camarinha-Matos
}

New University of Lisbon, Portugal

\section{Erratum to:}

\section{L.M. Camarinha-Matos (Ed.)}

\section{Collaborative Business Ecosystems} and Virtual Enterprises

\section{DOI: $10.1007 / 978-0-387-35585-6$}

The book was inadvertently published with an incorrect name of the copyright holder. The name of the copyright holder for this book is: (c) IFIP International Federation for Information Processing. The book has been updated with the changes. 